\title{
Anadolu Çömlekçiliğinde Gelenek ve İnanışlar
}

\section{Traditions and Beliefs in Anatolian Pottery}

\section{Dicle Öney}

Dr. Öğr. Üyesi, Sakarya Üniversitesi, Sanat Tasarım ve Mimarlık Fakültesi, Seramik ve Cam Tasarımı Bölümü email: dicleoney@sakarya.edu.tr DORCID ID: https://orcid.org/0000-0003-3139-2353

\author{
$\checkmark$ iThenticate" $\mathrm{Bu}$ makale bilimsel etik ve kurallara uygun hazırlanmıschers ve intihal incelemesinden geçirilmiştir. Etik kurul onayı \\ gerektirmemektedir.
}

Atıf (APA 6)/To cite this article

Öney, D. (2020). Anadolu çömlekçiliğinde gelenek ve inanışlar. Atatürk Üniversitesi Güzel Sanatlar Enstitüsü Dergisi, 26(45), 620-629. doi: https://doi.org/10.35247/ataunigsed.765301

Makale Gönderim Tarihi/Received: 06/07/2020

Makale Kabul Tarihi/Accepted: 22/09/2020

Makale Yayın Tarihi/Published: 22/10/2020

Research Article/Araștırma Makalesi

\section{Öz}

Anadolu topraklarında köklü bir geçmişe sahip olan çömlek üretimi, binlerce yıldır varlık göstermektedir. En eski üretimlerden günümüze kadar gelinen süreçte üretildiği toplumun yeme içme alışkanlıkları, sosyal yapısı, ekonomisi, gelenek, görenek ve inanışları gibi bir çok unsurla o toplumun kültürünü tanımlamaktadır. $\mathrm{Bu}$ yönüyle önceleri arkeoloji ve etnoarkeolojinin başlıca çalışma alanını oluşturmaktayken son yıllarda maddi kültür varlıklarının değer görmesiyle sosyal antropoloji, seramik sanatı ve tasarımı alanlarında da ilgi odağı haline gelmiştir. Anadolu'da 1900'lü yılların başından günümüze değin yüzün üzerinde çömlek üretim merkezi bulunmaktadır. Bu merkezlerdeki üretimler ile ilgili bir çok yayın bulunmakta ancak bu yayınlar çoğunlukla toprağın elde edilişinden pişirime kadar geçirdiği süreyi ifade eden teknik anlatımlarla sınırlı kalmaktadır. Oysa her merkezde birbirinden farklılık ve benzerlik gösteren birçok gelenek ve inanış bulunmaktadır. Bu araştırmanın amacı; Anadolu çömlekçiğinin gelenek ve inanışlarla ilgili verilerini sunmak, özellikle ülkemizdeki halkbilimi, folklor, antropoloji ve sosyoloji alanlarında çalışan bilim insanlarının ilgisini çekmek, bu çalışma alanlarına katkı sağlayacağı düşünülen bilgileri paylaşmaktır. Çalıșma verilerini; literatür taraması ve 2010-2015 yılları arasında Dokuz Eylül Üniversitesi Bilimsel Araştırma Projesi kapsamında yapılan "Günümüzde Anadolu'da Yaşayan İlkel Çömlekçilik Merkezleri”" başlıklı proje oluşturmaktadır. Araştırmada; çömlekçiliğin çıkışı, mesleğin kutsallığı, mesleğin önemi, ürünlerin pişirimi ve ürünlerin kullanım alanları ile ilgili gelenek ve inanışların olduğu saptanmıştır. Bu veriler; Meslek, Pişirim ve Ürünler ile ilgili gelenek ve inanışlar olmak üzere üç ana başlıkta incelenmiștir. Mesleğin rivayetler ile kutsal sayılması, devamlığının sağlanması ve gelecek nesillere aktarılmasında bir çok gelenek ve inanışın olduğu görülmektedir. Üretimin en önemli aşamalarından olan pişirimde deneyimle kazanılan bilgilerin inançlarla bağdaşlaştırılarak ritüellere dönüștüğü, ayrıca üretilen ürünlerin, toplumun sosyal yașam dinamiklerinden olan düğün ve ölüm olaylarında bir ifade aracı olarak kullanıldığı görülmektedir

Anahtar kelimeler: Çömlek, Çömlekçilik, Gelenek, İnanışlar, Anadolu

\begin{abstract}
Pottery production which has a long history in Anatolia has been in existence for thousands of years. It defines the culture of that society with many elements such as the eating and drinking habits, social structure, economy, traditions, customs and beliefs of the society in which it was produced from the oldest productions to the present day. From this aspect, while forming the main study field of archaeology and ethnoarchaeology in the beginning, it became the center of interest for field of social anthropology, ceramics art and design with the appreciation of material cultural assets in recent years. In Anatolia, there has been more than a hundred pottery production centers since the beginning of $1900 \mathrm{~s}$. There are many publications about the productions in these centers but these publications are limited with technical expression of the process from clay obtaining to firing. However, there are many different and similar traditions and beliefs in every center. The aims of this study is to submit data about tradition and beliefs in Anatolian pottery, to take the attention of the scientists who study in ethnology, folklore, anthropology, and sociology fields especially in our country, and to share the information that is thought to contribute these study fields. The study data consists of the literature review and the project titled "The Primitive Pottery Centers Present in Anatolia" which was conducted within the scope of Dokuz Eylul University Scientific Research Project between the years 2010 and 2015. In this study, it is obtained that there are tradition and beliefs about the emergence of pottery, the divinity of profession, the importance of profession, the firing of products and the usage of products. The data are analyzed in three main titles as the traditions and beliefs about Profession, Firing and Products. It is seen that there are many traditions and beliefs in divinity of profession with rumors, maintenance of its continuity and handing it down to next generations. In firing, which is one of the most important parts of production, it is seen that the knowledge gained with experience becomes ritual harmonized with beliefs and the products are used as a means of expression in weddings and deaths which are the social dynamics of community.
\end{abstract}

Keywords: Pot, Pottery, Tradition, Beliefs, Anatolia

\section{Giriş}

Çömlek; katı ve sıvı yiyeceklerin pişirildiği, korunduğu, düşük derecelerde pişirilen, topraktan yapılmış kap olarak tanımlanmaktadır. Günlük kullanım amaçlı üretilen sıradan ve basit gibi görünen bu kaplar üretildiği toplumun kültürünü tanımlamasıyla çoğunlukla arkeoloji alanında değerlendirilmekteyken son yıllarda etnoarkeoloji, sosyoloji ve antropoloji alanlarında da değer kazanmıştır. Bu alanlarda yapılan çalışmalar incelendiğinde ilkel şartlarda üretilen çömleklerin; kil çıkarma, biçimlendirme, bezeme ve pişirim süreçleri sırasında karşılaşılan tabular, gelenekler ve inanışların yanı sıra üreten kişilerin toplumdaki statüsü ve ürün türlerine yüklenen sosyolojik olgular gibi birçok verinin irdelendiği gözlemlenmiştir. Maddi kültür varlıklarından biri olan çömlek, Anadolu topraklarında binlerce yıllık üretim geçmişine sahiptir. 1900'lü yılların başından günümüze yapılan alan araştırmaları ile yüzün üzerinde üretim merkezinin bulunduğu tespit edilmiştir. Çömlekçilik ile ilgili bir çok alan 
araştırması bulunmaktadır. Sarıtaş’ın da (2019, s. 32) belirttiği gibi “bu çalışmalar belirli bir yörenin geleneksel el sanatı ve ustası, halkbilimi bağlamında ele alınarak unutulmaya yüz tutmuş bir kültürel değer olarak aktarılmıştır”. Şüphesiz yapılan bu çalışmaların alana sağladığı katkı tartışılamayacak boyutta önem arz etmektedir. Ancak değişen ve gelişen sosyoloji ve antropoloji alanlarına zengin kültürel birikimi ile katkı sağlayacak Anadolu çömlekçiliği hakkındaki bilgilerin paylaşılması da ayrıca önemlidir. Bu bağlamda, Anadolu Çömlekçiliği ile ilgili 2010-2015 yılları arasında yapılmış bilimsel araştırma projesi kapsamında elde edilen bilgi, belge ve kayıtlar konunun tarihe 1 şı tutan en yakın verilerini sunmasına olanak sağlamıştır.

Makale kapsamında, Anadolu çömlekçiliğinde karşılaşılan gelenek ve inanışlar; mesleğin çıkışı ve buna bağlı ritüeller, usta-çırak ilişkileri, farklı coğrafi bölgelerde mesleğe verilen değer ve önemle ilgili kayıt altına alınmış söylenceler, pişirim ile ilişkili uygulamalar ve ürünler sınıflandırılmıştır.

\section{Yöntem}

Bu çalışmada nitel araştırma yöntemi kullanılmıştır. Çalışma verilerini; 1900-2020 yılları arasında yayınlanmış literatür taraması ve 2011.KB.SOS.010 numaralı "Günümüzde Anadolu'da Yaşayan İlkel Çömlekçilik Merkezleri” başlıklı Dokuz Eylül Üniversitesi Bilimsel Araştırma Projesi kapsamında kaynak kişiler ile yüzyüze yapılan görüşmelerden elde edilen bilgiler oluşturmaktadır.

\section{Bulgular}

Anadolu'nun farklı coğrafi bölgelerinde bulunan çömlek üretim merkezlerinden elde edilen bulgular, üç başlık altında toplanmıştır.

\subsection{Meslek ile İlgili Gelenek ve İnanışlar}

Mesleğe değer katmak, yapılan uğraşı kutsal saymaktan geçmektedir. Bu sebeple çömlekçilere; mesleğin yörede ilk kimler tarafından yapıldığını biliyor musunuz? sorusunun genellikle ilk cevabı "peygamberler" olmuştur. Anadolu çömlekçiliğinde mesleğin çıkışı ile ilgili birbirinden farklı inanışlar ve bunlara bağlı rivayetler bulunmaktadır. Ankara Şereflikoçhisar'daki rivayete göre: "Peygamber tezgâhın üzerine çamuru koymuş, eli çamura yapışmış ve ağlayarak 'Yarabbi bu çamur elime yapıştı elimi bırakmıyor' demiş, gözyaşı elini ıslatarak çamurun üzerine akınca tezgah dönmüş ve biçimlendirmeye başlamış, böylece çömlekçilik başlamıştır (Kargın, 2012).

Gelenek ve göreneklerin inançlarla yoğun biçimde harmanlandığı görülen Diyarbakır ve Mardin'de ise bu inanış Nuh Tufanı ile özdeşleşmekte ve nesilden nesile şu şekilde aktarılmaktadır:

... Zorlu günlerin ardından tufan sona erip, sular çekildiğinde Nuh'un gemisi Cudi dağına oturmuştur. Her türlü sıkıntının çekildiği, kabın kapkacağın bulunmadığı bu dönemde, Cebrail (A.S) gelmiş ve Nuh Peygambere toprağı tanıtarak, kilden çömlek yapmayı öğretmiştir. İlk gemiyi icat eden, aynı zamanda ilk çömleği de yapan Nuh Peygamber tufandan sonra elli yıl daha yaşayıp, soyuna hem hayır dualarını hem de çömlekçiliğin bu ilginç öyküsünü anlatmıştır (Daşdağ, 2001, s. 12).

Geleneksel üretimin neredeyse birçok aşamasında farklılık gösteren kadın ve erkek üretiminde, özellikle kendi yöresi dışında yapılan üretimlerden haberdar olmayan her merkezde mesleğin sadece "kadın" ya da sadece "erkek" tarafından yapılacağına inanılmaktadır. Şüphesiz bu inanç nesilden nesile aktarımda söz konusu ustanın cinsiyeti ile alakalıdır. Ancak bu cinsiyet ayrımı, mesleğin çıkışıyla ilgili olan inanışlarda da bulunmaktadır. Çömlekçilik; Diyarbakır, Mardin ve Şereflikoçhisar'daki gibi erkek üretiminin yapıldığ1 yerlerde "Nuh peygamber ve Hz. Muhammed" soyundan gelmekte iken kadın üretim merkezi olan Kastamonu'ya bağlı Küçüksu köyünde "Hz. Muhammed'in kızı Hz. Fatma'dan” miras kalmıştır. Yöredeki söylentiye göre; "bir gün aş pişirecek kap bulamayan Hz. Fatma çaresizlikten çamuru oymuş, onu pişirmiş sonra da aş pişirmek için kullanmıştır. Bu sebeple köyde pişmiş topraktan yemek yemek sevaptır" (Güner, 1988, s. 47).

Bu inanışlarla mesleğin kutsal olarak addedilmesi yöre halklarının yaşamında karşılaştı̆̆ bazı güç durumlar için umut vadetmelerine de sebep olmuştur. Örneğin Diyarbakır'da üretimin devam ettiği dönemlerde "evlenmeleri gecikmiş kızlar üst üste üç Cuma günü niyet tutarak, öğle namazından önce çömlek atölyesine getirilir, çarkın kellesine çıkıp, yüzü kıbleye çevrilerek niyet tutup, kısmeti açılır diye yedi defa döndürülür (Daşdăg, 2001, s. 12; Ünal, 1996, s. 70). Çömlekçi çarkı, yakınları evden kaçan ya da gurbete giden aileler tarafından da umut vadetmektedir. Ustaya "kişinin gömleğini çarkın demirine bir hafta sürece bağlatarak, çark döndükçe kaçan kişinin sıkılıp hasrete dayanamaz hale geleceğine ve eve döneceğine inanılır. Kısmeti açılan kızların ve gurbetten dönenlerin aileleri umutları gerçekleştiği için çömlekçilere çeşitli hediyeler vermektedir" (Daşdağ, 2001, s. 13). 


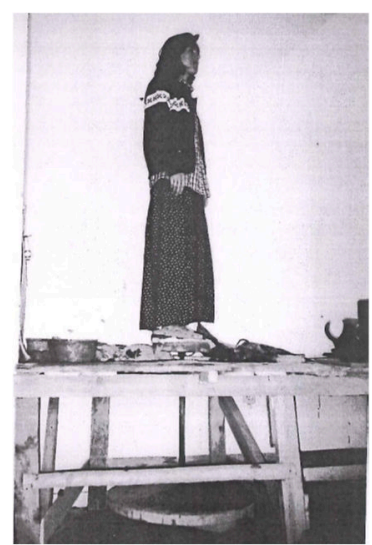

Görsel 1. Kısmeti açılması için çarka çıkıp niyet tutan genç kız

Söz konusu inanışlar olduğunda halk arasında kutsal mesleği yapmanın önemi büyüktür. Bu durum, mesleğe rağbetin artması, mesleğin yaygınlaşması ve nesilden nesile aktarılmasını sağlamış olabilir. Bununla birlikte dönemin ihtiyaçları doğrultusunda ürünlerin sıklıkla kullanılması arz talep ilişkisini arttırarak sonuçta büyük ölçüde kazanç sağlanması gözardı edilemeyecek unsurdur. Gelir getiren meslek olması birtakım geleneklere de yol açmıştır. Bu geleneklerden birine Eskişehir ili Mihallıççık ilçesine bağlı Sorkun ve Gökçeayva köyleri ile Gümüşhane'ne merkeze bağlı Dölek köyünde rastlanılmaktadır. 1970’li yıllarda “bu sanatı başka yere götürmelerini önlemek amacıyla kızların dışarıya gelin verilmediği bilinmektedir” (Güner, 1988, s. 40; Arı, Kişisel İletişim 6 Mayıs 2020). Ayrıca mesleğin yapıldığı hanenin soyuna ait olması durumuna da rastlanılmaktadır. Özellikle diğer köylerden gelin gelen kıların bu uğraşı yapmamaları için Ordu ilinin Mesudiye ilçesine bağlı Alişar köyünde "çömlekçilik yalnızca kaynanalar tarafından yapılmıştır” (Güner, 1988, s. 16).

Çömlekçilik, 1900’lerde erkek üretimin söz konusu olduğu bölgelerde çoğunlukla Ermeni ustalar tarafindan yapılmaktaydı. Bu ustalar, mesleğin aktarılması hususunda birtakım gelenekler uygulamaktaydı. Meslek, öğrenmeyi talep edenler yerine özenle seçilmişlere, dört tarafi duvarla çevrili, pencereleri özellikle bu duvarların en yüksek yerlerine konumlandırılmış işliklerde öğretilmekteydi. Öğrenmeye hevesli fakat ustalar tarafından seçilmemiş meraklı gençler, işliklere dışarıdan merdiven vb. nesneler yardımıyla duvarlara çıkıp izleme yoluyla öğrenmeye çalışmışlardır. O dönemlerde Ermeni ustaların işliklerinin bulunduğu yerlerden biri de Konya Bozkır ilçesi Çağlayan köyüdür (yaygın kullanımı ile Çat). Hüyük ilçesinden İnce Şükrü, Sarıların Ali ve Fahri Bardakçı, Ermeni ustalar tarafından seçilmiş gençler arasında yer almaktadır. Çömlekçilik, o dönemlerden günümüze kadar Konya'nın Hüyük, Doğanhisar, Sille, Meram gibi birçok ilçesinde yapılmaktadır. Hüyük’te üretime devam eden İsmail Arıkan'ın ustası Hasan Ali Sarıaslan seçilmemiş fakat mesleği merakla gizlice öğrenen ustalardandır. İsmail ustanın aktardığına göre (2012); o da bu mesleği öğrenmek için günler ve haftalarca ustasının kapısından ayrılmayarak çabalayanların arasında yer almaktadır.

Mesleğin, Ermeni ustalardan bahsi geçen şartlar altında öğrenilmesi Elazı̆̆’ın Peri ilçesinde de (günümüzde Tunceli Akpazar ilçesi) rastlanılmaktadır. Üretimine devam eden Halil Bozkurt, ustası Mehmet Kuzu'nun izleyerek öğrenmeye çalışanlardan olduğunu dile getirmiştir. Ancak Mehmet Kuzu, izleyerek öğrenmenin yetersiz olacağını düşünerek iki reşat altını karşılığında Ermeni bir ustadan bu mesleği öğrenmiştir (Bozkurt, 2012).

Vaktiyle mesleğin bu denli korunup kollanması, özenle seçilmiş kişilere aktarılması ve devamlılığını sağlama çabaları ile toprak kapların o dönemlerde sıklıkla kullanılması dolayısıyla ekonomiye getirdiği katkı sayesinde vazgeçilmez mesleklerden biri olmasını sağlamıştır. Öyle ki toplum içinde önemli bir yer tutan çömlekçilik, gelin veya damat adayları seçiminde de önemli bir yer edinmiştir. 1950'li yıllarda Avanos’ta "çanak yapmayana kız vermezler" (Tüzün, 2018), üretimin kadınlar tarafından yapıldığı yörelerde ise bu uğraşı bilmeyen kızlar evde kalırlarmış.

Anadolu'da uyguladığı ilkelerle meslek ahlakını kurup koruyan Ahi Dernekleri'nin töre düzeyinde birtakım kuralları bulunmaktadır. Ali Rıza Balaman "Kütahya'da Geleneksel Seramikçilik” adlı araştırmasında bu kuralları şöyle açıklamaktadır:

.... kalfalıktan ustalığa geçişte, törenle ustasından “el alan” (destur, izin alan) kalfa, kendi seramik işliğini açtığında kalfanın ustası başta olmak üzere öteki ustalar yeni iş sahibine seramiğin ana maddesi olan çamuru, on yıl süreyle ücretsiz olarak verirlerdi. Yeni işlik sahibi ustada da, ilk yıldan başlayarak her yıl için belirli bir oranda çamuru, çamur havuzunda yapar ve onu, on yıl süreyle işlemden geçirir, on yıl sonra kullanmaya hazırlardı. Özetle on yıllık bir geçmişi olmayan hamur, seramik yapımında kullanılmazdı. ...destekleme töresi uygulanmasaydı işlik sahipleri ancak on yıl sonra üretime başlayabileceklerdi (Balaman, 1985, s. 55-56). 
Balaman'a (1985:56) göre, böylece yeni usta adayları bu gelenek sayesinde kendilerine yapılan bu desteği mesleğin yeni üyelerine aktararak hem mesleğin devamlılığını sağlamış hem de ustalarına olan borçlarını bu yolla ödemiş olacaklardır.

\subsection{Pişirim ile ilgili Gelenek ve İnanışlar}

Çömlek üretiminde nihai ürüne ulaşmanın en kritik ve önemli aşamalarından biri pişirimdir. Özellikle firının olmadığı ilkel pişirim yöntemlerinden olan açık alan pişiriminde deneyim ve bu deneyimin nesilden nesile doğru biçimde aktarılması büyük önem arz etmektedir. Bu sebeple deneyimlerden elde edilen olumsuz sonuçları önlemek amacıyla birtakım kurallar bulunmaktadır. Bu kuralların bazılarının zamanla inanışa dönüştüğü de görülmektedir. Örneğin 1920'li yıllarda üretimin yaygın olarak devam ettiği Gaziantep'in Oğuzeli ilçesine bağlı Alimantar, Üçkubbe ve Zıramba köylerinde pişirim, açık alanda tezekle yapılmaktaydı. Üretimin kadınlar tarafindan yapıldı ̆̆ bu köylerde "ateşin arsız bir avrat tarafından yakılmasına dikkat edilmekte, böylece pişirilen kapların dayanıklı olacağı inancı yaygındı” (Yalgın, 1940, s. 197). “Arsız avrat” cabbar, elinden iş gelen kadını tasvir etmekte, ateşin çömlekler pişene kadar sönmeden yanması için böyle bir karakter ile özdeşleştirmeye ihtiyaç duyulmaktadır.

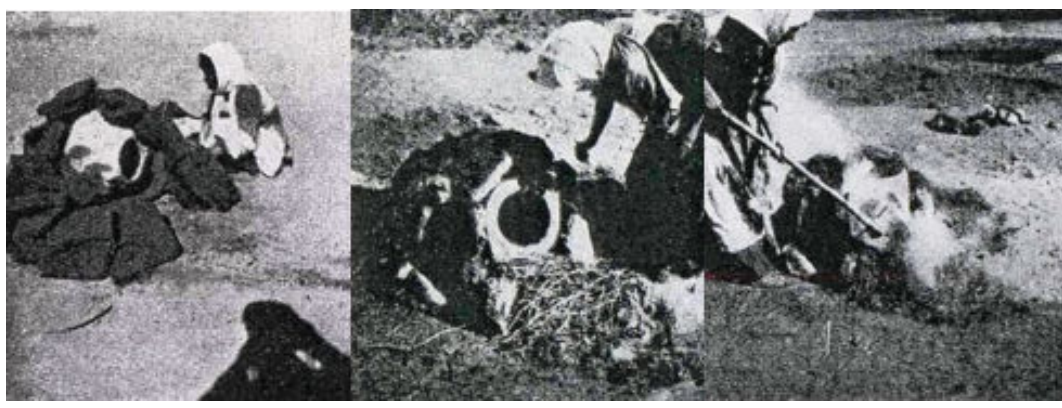

Görsel 2. Gaziantep köylerinde açık alan pişirimi yapan kadın

Elazığ'ın Sivrice ilçesine bağlı Uslu köyü ve diğer birçok açık alan pişirimi yapılan üretim merkezlerinde de pişirim için rüzgârlı bir gün olması beklenmektedir, yoksa kapların iyi pişmeyeceğine inanılmaktadır. Gökeyüp köyündeki çömlekçiler pişirimin doğru zamanda yapılması için; 'rüzgârsız havada yapılan pişirime 'tonuk', rüzgârın şiddetli estiği zamanlarda yapılan pişirimde ise kümenin dışında kalan rüzgarla fazla temas eden kapların parlamasına 'şılak' adını vermişlerdir" (Güner, 1988, s. 35). Tonuk sonucunda kaplar çabuk aşınır ve dayanıksız olur, Şılak sonrası ise kapların görünümünde renk açısından farklılıklar olmakta bu da kapların sorunlu olarak algilanmasına sebep olmaktadır.

Alimantar, Üçkubbe ve Zıramba köylerinde, açık pişirimde yakıt olarak kullanılacak tezeklerin seçimi de önemlidir. "Bu tezeklerin sadece sığırdan olması, diğer hayvanlar ya da insan atığından olmaması gerekmektedir. Aksi halde pişirim esnasında çömleklerin kırılacağı inancı yaygındı” (Yalgın, 1940, s. 197).

Sivas ilinin Zara ilçesine bağlı Demiryurt (eski adıyla Tödürge) köyünde ise "pişirim, ateşin gece yaş davar gübresiyle kaplanması, gündüz tekrar açılmasıyla üç gün sürdürülmekteydi. Bunun nedeni bu tür pişirimle işlerin daha sağlam olacağı kanısıdır" (Güner, 1988, s. 45).

1940'lı yıllarda Sorkun'da üretimde kullanılan çamurun hazırlanma esnasında içine yabancı bir madde karıştırılmamasına çok özen gösterilirdi. "Bir saman çöpü bile karışsa bu çamurdan yapılan çömleğin pişerken çatlayacağına inanılmaktadır. Yine deneyimler sonucunda edinilen bu bilgiyi doğrularcasına yörede o dönemde çatlayan çömleklere 'dene çetiği olmuş’ denilmektedir”' (Yalgın, 1945, s. 81).

1920’li yıllarda, Manisa ili, Salihli ilçesine bağlı Gökeyüp köyünde ise pişirim yine açık alanlarda ancak belirli günlerde yapılmaktaydı. Özellikle "pişirimin Perşembe günü yapılması tercih edilirken, pişirimin yapıldığg günün ertesi günü çamaşır yıkamanın adet olduğu bilinmektedir” (Koşay ve Ülkü, 1962, s. 92). Bu gelenek günümüzde geçerliliğini yitirmiştir.

\section{3. Ürünler ile ilgili Gelenek ve İnanışlar}

Çömlekler her ne kadar mutfak ihtiyacını karşılayan günlük kullanım amaçlı üretilen nesneler gibi düşünülsede toplum kültürünü yansıtan düğün, bayram ve ölüm gibi birçok geleneksel törene de hizmet ettiği görülmektedir. Formların genellikle ölüm olgusu ile ilgili inanışlarda sıklıkla kullanılması çömlekçiliğin başlangıcı olarak anlatılan rivayetlerdeki kutsal olma durumuyla ilişkili olabilir.

Diyarbakır'da 1930-1940'lı yılların gelenekleri arasında bir vefat sonrası taziye evinden yayvan, yeşil sırlı bir çanakla, her gün bir ögün olmak üzere kırk gün boyunca yoksulları doyurmak ta yer almaktadır. Bu sırlı çanaklar yemekle birlikte hediye edilmekte, ölen kişinin sevabına kırk gün, kırk ayrı çanakla kırk yoksul doyurulmaktadır (Daşdağ, 2001, s. 14). 
Ayrıca yörede kurban bayramlarında satılmak üzere özel çömlekler de üretilmekteydi. Küçük yaşta ölen çocukların hayrına kurban bayramlarında "Cirdon veya Mezarlık Testisi adı verilen kulplu küçük testilere su doldurup ağız kısmına elma koyularak küçük çocuklara verilirdi” (Ünal, 1996, s. 70). "Mahşerde güneş birinci kata inip, yakıcı sıcaklığını hissettirdiğinde ölmüş çocukların bu kaplarla anne ve babalarına su getirdiğine inanılmaktadır" (Daşdağ, 2001, s. 13).

Mardin'de ise aynı amaç için "İşrebül Kadir" olarak adlandırılan kulpsuz, bardak biçiminde bir form üretilmektedir. "Çocuğu ölmüş aileler tarafından satın alınan bu bardaklara ailenin ekonomik durumuna göre su ve elma dilimi, leblebi veya şeker konularak mezar başında bayram süresince çocuklara dağıtılır” (Kaynak, 2012). $\mathrm{Bu}$ dağıtım Kurban bayramlarının birinci günü ve Kadir gecesinde çocukların ruhuna değmesi amacı ile yapilmaktadir.

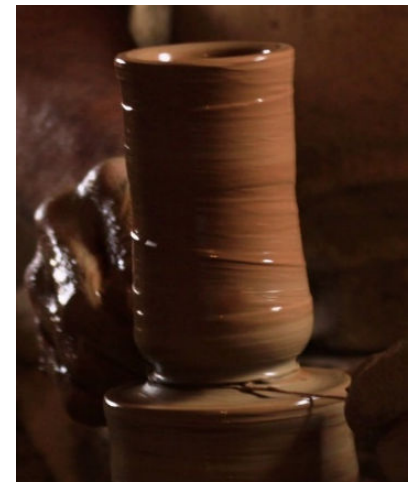

Görsel 3. İşrebül Kadir

Ordu ili Ünye ilçesinde çömlekçiliğin yaygın olarak yapıldığı 1960-70’li y1llarda cenazeler için "ölü çömleği”" üretilmekteydi. "Bir ibrik ve dört çömlekten oluşan beş parçalı bu takım ölü yıkamada kullanılmaktaydı. 'Topraktan geldik toprağa gidiyoruz' ifadesiyle toprak kapların kullanılmasının sevap olduğu inancı yaygındı" (Karayiğit, Kişisel İletişim 1 Mayıs 2020).

Muğla’nın Fethiye ilçesine bağlı eski adı Dont olan Esenköy’de, "Buhurdanlık” adı verilen kulplu kupa biçiminde bir kap üretilmektedir. "Yörede ‘A ğar Günü' olarak adlandırılan Perşembe ve Pazar günleri ölüleri anmak ve kötü ruhları kovmak için kullanılmaktadır. Bu özel günlerde buhurdanlığın içine günlük ağacı kabuğu konularak yakılır ve evin her odası dolaşılıp kokunun etrafa dağılması sağlanır” (Köse, 2015).

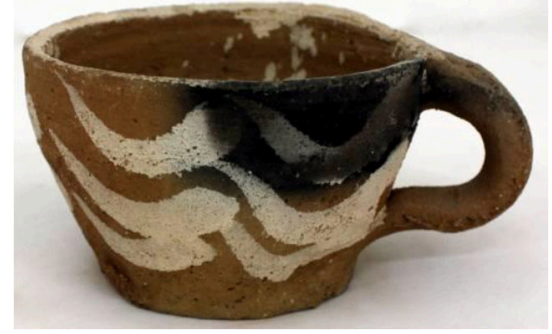

Görsel 4. Buhurdanlık

Şanlıurfa'nın Sırın köyünde çömlekçiğin devam ettiği dönemde Külünçe ekmek tandırı üretilmekteydi. Bu tandır adını yörede üretilen "Külünçe” adlı çörekten almaktadır. Külünçe, "asker uğurlamasında" (Yiyin, 2009, s. 105), "Ramazan ayında, dini bayramlarda, kutsal gecelerde ve vefat eden kişinin kırkıncı gününde pişirilmektedir" (Daşdağ, 2005, s. 91).

Çömlekçilikte yaygın olarak üretilen formların başında testi yer almaktadır. Testiler, su taşımak veya depolamak amaçlı üretilmelerinin yanısıra düşüncelerin, duyguların ifade edilmeye çalışıldığı anlatım aracı olarak da karşımıza çıkmaktadır. Aydın Karacasu ilçesinde üretilen "Gelin Testisi” veya diğer adıyla "Gelin Bardağı" buna en uygun örneklerden biridir. Yaklaşık iki asırdır üretilen bu form, yöre halkı tarafından kullanılmaya devam etmektedir. Yöredeki rivayetlere göre; bir gelin doğacak çocukların kumalardan değil kendisinden olması için Allah'a dua eder ve bir çömlekçiye gidererek endişelerini paylaşıp ondan bir bardak yapmasını ister. Usta, gelinin isteği üzerine Gelin Bardağı'nı tasarlar. Yörenin deneyimli ustalarından Hamdi Kirişçi’nin tasarıma yeni yorumlar katarak ürettiği form yirmi dokuz parçadan oluşmaktadır. Üç ağızlı, iki kulplu ve altı emzikli formda, ağızlar evdeki kadınları, emzikler ise çocukları ifade etmektedir. Sadece ortadaki ağız kısmı açık iki yandakiler ise kapalı ve işlevsizdir. Açık olan ağız testiye sahip olan kadını, diğerleri ise kumaları simgelemektedir. Altı emziğin etrafına işlenmiş zincir figürü ise bu çocukların yalnızca tek bir kadından olmasını ifade etmektedir. Testide ayrıca 
iki erkek, iki kadın figürü ve bir gül motifi bulunmaktadır. Kulpların altına yerleştirilen bu figürler estetiği arttırmak ve simetri ile dengeyi sağlamak içindir. Gül motifi ise kadının, kumalar gelmeden önceki güzel günlerini temsil etmektedir (Kirişçi, Kişisel İletişim 9 Mayıs 2020). "Yörede, diğer ustalar tarafindan birbirinden farklı yorumlarla üretilmiş Gelin Testisi örnekleri de mevcuttur” (Yardımcı ve Bardak, 2019, s. 93).
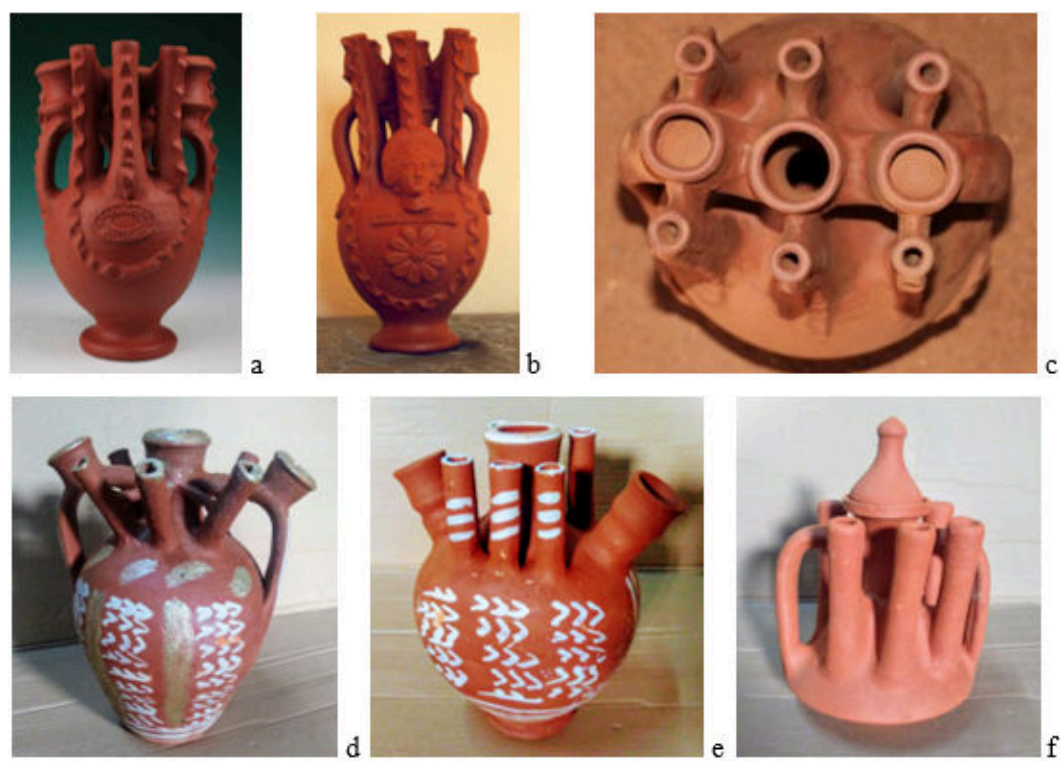

Görsel 5. Gelin Bardağı örnekleri

Testi, 1980'li yıllarda Samsun'un Çarşamba ilçesinde ise bir iletişim aracı olarak kullanılmaktaydı. "Evlerin bacasına kızların sayısı kadar testi boynu dikilir, o hanede yaşayan kıza talip olan genç delikanlı bir sapan yardımı ile testi boynunu kırarak evlenmek istediğini dile getirmektedir. Bu olaydan sonra kız evi oğlan evinin kızlarını istemelerini bekler eğer isteme gecikirse 'oğlunuz bizim bacadaki testi boynunu kırdı; neden onarmıyorsunuz?' diyerek oğlan evine haber göndermektedir (Balaman, 1983, s. 135)”

Anadolu'nun birçok yöresinde testi kırma; düğün, kına gecesi ve asker uğurlaması gibi özel günlerde yapılan ritüellerdendir. Mardin'de üretilen "Şerboy" adı verilen testi dügün günü kayınvalide tarafından içine şeker ve para doldurarak geline verilir. Gelin yeni evine girerken testiyi kırar, yere dağılan para ve şekerler hem çocuklar hem de büyükler tarafından toplanır. Özellikle büyükler bu paraları şans parası olarak saklarlar. Evin kapısında kırılan bu testi sayesinde kurulan yeni ailenin uğursuzluklardan korunacağına inanılmaktadır (Koğumtekin, 2012). Testinin içine, Anadolu'nun birçok bölgesinde su, ceviz, üzüm, buğday gibi bereketin ve bolluğun simgesi olan diğer yiyecekler de konulmaktadır. Testi kırmanın sonucunda; "uğur getireceğine, etrafa dağıtılan suyun kutsal sayılarak getireceği saadete, uzun ömürlü birlikteliğe, gelinin kötü huylarının geride bırakılmasına, huysuzluklarının ve sıkıntılarının baba evininden gelin geldiği yere taşınmamasına (Koç, 2016, s. 267-269) ayrıca kırıldığında çıkarılan sesin kötü ruhları kovduğuna inanılmaktadır" (Akça, 2009, s. 79). Asker uğurlamasında ise "testi içine su konulur, uğurlayan kişiler ağız kısmına para koyar ve askere gidecek delikanlı bir tekme ile testiyi kırar. Testinin içinde kalan su bu delikanlının üzerine serpilir. Paralar harçlık olarak alınır" (Martin, Kişisel İletişim 21 Nisan 2020). Testinin kırılması asker olan delikanlının erişkinliğini, üzerine serpilen su ise askerliğini kazasızbelasız bitirmesine olan temenniyi temsil etmektedir.
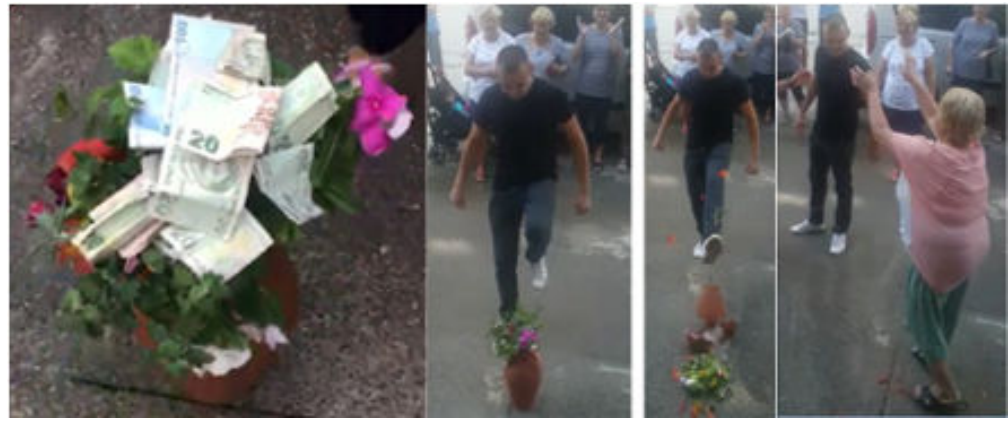

Görsel 6. Asker uğurlamada testi kırılması

Testinin adak olarak kullanılmasına da rastlanılmaktadır. Vaktiyle, "Bolu'nun Yumrukaya köyünde Hıdırellez günü evlenmemiş genç kızlar ellerinde testi ile ev ev dolaşarak, verilen gümüş takıları toplayıp, takılarla dolu testiyi gül ağacının altına gömüp dilek tutarlarmış" (Tuncer, 2017, s. 50). 
Çocukları eğitmek amaçlı üretilen testiler de bulunmaktadır. "Mardin'de üretilen Şerboy testisi, düğün törenlerinin yanısıra çocukların eğitimi amacı ile de kullanılmaktadır” (Koğumtekin, 2012). Konya'nın Doğanhisar ilçesinde aynı amaç için üretilen testiye "Çocuk İşi”" adı verilmektedir. Bu testiler çocuklara verilerek su getirmesi istenir. Böylece çocuk tek başına bir işi yapmaya, sorumluluk kazanmaya alıştırılmaktadır (Eğidoğan, 2012). Testi uzunluğu, taşımada kolaylık sağlanması amacıyla 20 santimetreyi geçmemektedir.

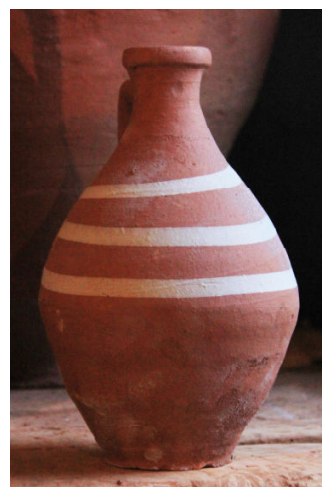

Görsel 7. "Çoçuk İşi”" adlı testi

Anadolu çömleklerinde bezemeye sıklıkla rastlanmaktadır. Elazığg'ın Sivrice ilçesine bağlı Uslu köyünde 1980'li yıllarda üretilen küpler üzerinde rölyef biçiminde bezemeler görülmektedir. Ertuğ $(2004$, s. 88) o y1llarda yörede yaptığı alan araştırmasında küplerin üzerine yapılan bu bezemeleri kilim ve halılarda işlenen doğurganlığın ve bereketin simgesi olan hayat ağacı motiflerine ayrıca yine aynı küpler ve kapların üzerinde yer alan dalgalı rölyefleri güneşe benzetmektedir. O dönemlerde ustalara bu şekillerin kaynağını sorduğunda ise "annemizden ne öğrendiysek onu yapıyoruz" cevabını almıştır (Ertuğ, 2004, s. 88). 2012 yılında tarafımızdan yörede yapılan alan araştırmasında son kalan usta küp üretmemekle birlikle yaptığı güveçler üzerinde bezeme bulunmamaktaydı.
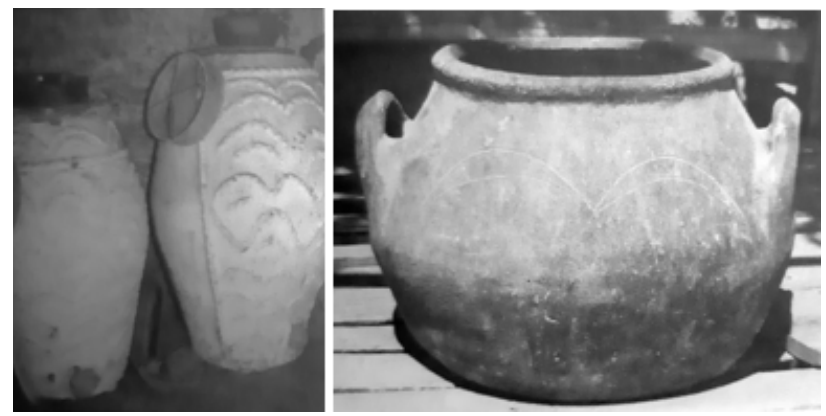

Görsel 8. Bezemeli küp ve güveç örneği

1920’lerde Oğuz Türkmenlerinden olan Alimantar, Üçkubbe ve Zıramba köylerinde su küpleri üretilmekteydi. Yalgın (1940, s. 201), bu su küplerinin üzerinde bulunan bezemeleri yörede yapılan damgalara benzetmektedir. Yöre halkı, "başa giyilen serpuşların içini ev duvarlarının muhtelif yerlerini nazar değmemesi ve güneşin yakmaması için aşı boyası ile damgalamaktadır” (Yalgın, 1940, s. 201). Yalgın'ın Türkmenler üzerine yaptığı bir başka araştırmada bu damgalara benzeyen diğer damga örneği Kilis’te bir düğün evinin kapı duvarlarında görülmektedir (Yalgın, 1977, s. 149). 1970'li yılların sonlarına doğru üretimin bittiği bilinen Zıramba köyünde 2015 yılında tarafımızdan yapılan alan araştırmasında eski ustalar, bezemelerin anlamını bilmediklerini büyükleri ne öğrettiyse onları yaptıklarını dile getirmişlerdir.
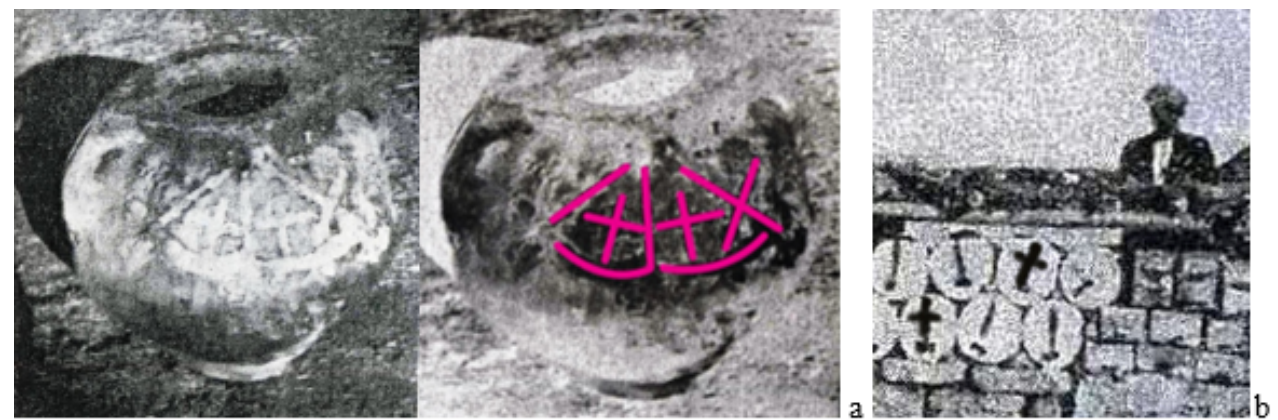

Görsel 9. Damgalı su küpleri ve arı kovanları 


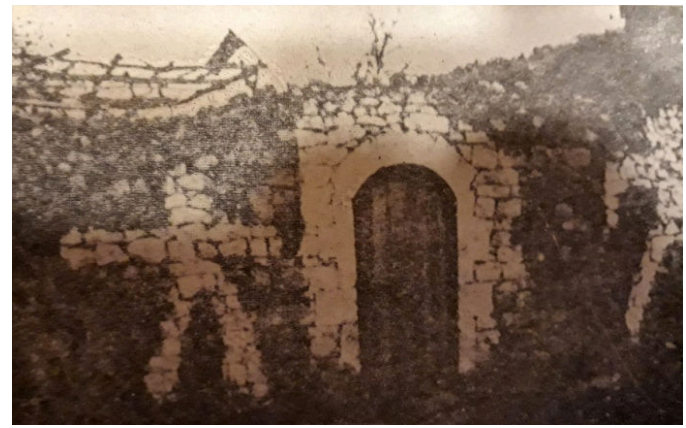

Görsel 10. Düğün evi kapısı, Kilis

\section{Sonuç}

Gelenek ve inanıșlar, bir toplumun tüm dinamiklerini içinde barındıran, kültürünü tanımlayan sosyal olușumlardır. Özellikle Anadolu toprakları, konumu ve tarihi göz önünde bulundurulduğunda birden çok toplumun yaşadığı, farklı kültürleri içinde barındıran kozmopolit bir yapıya sahiptir. Anadolu çömlekçiliği için de aynı durum söz konusudur. Örneğin; kadın ustaların üretim yaptığı merkezlerde çoğunlukla Türkmen oldukları, erkek ustaların üretim yaptığı merkezlerde ise mesleği çoğunlukla Ermeni ve Rum ustalardan öğrendikleri bilinmektedir.

Göç ederek geldikleri Anadolu topraklarına kendi kültürlerini taşıyan kişi veya gruplar da yeni yerleştikleri ve mesleği öğrendikleri bölgelerde, gelenek ve inanışlarının çeşitlenerek zenginleşmesine katkı sağlamışlardır.

Anadolu'nun farklı bölgelerinde var olan çömlek üretimlerinde, mesleğin çıkışı ile ilgili inanışların benzerlik gösterdiği gözlemlenmektedir. Mesleğin peygamberler soyundan gelmesi, yapılan işin, uğraşın değerini olabildiğince yüceltmektedir. Bu durumun, mesleğe saygının ve rağbetin artmasına sebep olduğu görülmektedir.

Çömlek üretimini yapan kişinin cinsiyetine bağlı olarak rivayetlerde de peygamberlerin Nuh ve Hz. Fatma olarak ayrılması söz konusudur. Örneğin, Diyarbakır'da erkek çömlekçilerin Nuh, Kastamonu Küçüksu köyünde ise kadın çömlekçilerin Hz. Fatma'yı referans alan rivayetlere inanması gibi.

Çömlekçiliğin, peygamber mesleği olarak kabul edilmesi sebebiyle kayıpların bulunması, evde kalan kızların kısmetinin açılması gibi durumlarda usta ve atölyelerinin adeta medet umulan yer ve kişiler olarak görülmesine sebep olmuştur.

Toprak kapların kullanımının yaygın olduğu 1960’lı yıllara kadar gelinen süreçte çömlekçiliğin değerli, emek ve kabiliyet isteyen kazançlı bir meslek olması; gelin alıp vermeyerek yöre halkı dışında bu uğraşı yapmayı yasaklama, gelin veya damat adaylarının seçiminde mesleğin büyük rol alması, meslek adaylarının özenle seçilmesi ve her isteyenin bu uğraşı yapamayışı gibi neredeyse tabu sayılacak geleneklere sebep olmuştur.

Çömlek üretiminin son aşaması olan pişirim, ürünün elde edilmesinde en önemli safhadır. Bu sebeple, pişirim ile ilgili deneyimlerin gelecek kuşaklara aktarımı mesleğin sağlıklı bir şekilde yürütülmesi için gereklidir. Pişirim esnasında kullanılacak yakıt türü, ürünlerin doğru dizilimi ve rüzgâr yönünün hesaplanması gibi unsurlar kuşkusuz tecrübe ile ilgili en önemli faktörlerdir. Fakat tüm bu uygulamaların yanı sıra pişirimin sorunsuz gerçekleştirilebilmesi için özel ve kutsal günlerin seçilmesi veya ateşin cabbar bir kadın tarafından yakılması gibi ritüellere de ihtiyaç duyulmuştur.

Ürünlerin, özellikle düğün ve ölüm gibi önemli sosyal olaylarda bir ifade aracı olarak kullanılmasına sıklıkla rastlanılmaktadır. Düğünlerde kırılan testi; yeni oluşumları temsilen kötü olan her şeyi geride bırakma, gelinkayınvalide ilişkisinde söz sahibi olma, üstün olma gibi bireysel isteklerin dışında kötü ruhlardan arınma gibi inançları sembolize etmektedir. Ayrıca testi içine konulan ve bereketi simgeleyen nesnelerin etrafa saçılması ile yeni bir aile oluşumunda bolluk ve kazancın daimi olması umulmaktadır. Günümüzde Karacasu'da üretimine devam edilen Gelin Bardağı'nın her ne kadar kumalığın söz konusu olmadığı bir yöre olmasına karşın hala kullanılıyor olması inancın ve geleneğin vazgeçilemez olduğunu göstermektedir.

Vaktiyle Diyarbakır'da ve günümüzde Mardin'de üretilen, çocuğu ölen aileler tarafından satın alınan testiler, öteki dünyada ölen çoçuklara ithaf edilse de, aynı zamanda üretim sayılarına bakıldığında söz konusu bölgelerde çocuk ölümlerinin ne kadar yaygın olduğunu da göstermektedir.

Anadolu çömlekçiliğinde sıklıkla rastlanılan bezemelerin Uslu, Zıramba, Alimantar ve Üçkubbe köyleri örneklerinde olduğu gibi yalnızca süsleme amaçlı yapılmadığı aynı zamanda bereket ve nazar inançlarını simgelediği görülmektedir. Günümüz üretimlerinde de bezemeler uygulanmaktadır ancak ustalarla yapılan görüşmelerde bezemelerin anlamlarına dair bilinçli bir üretimin olmadığı anlaşılmıştır. Örneğin sıklıkla kullanılan bezeme türlerine dair sorulara; "ustamdan böyle gördüm", "annemden ne öğrendiysem onu yapıyorum", “süslüyoruz” veya "bunu yapmazsam olmaz, bizim ürünümüz olduğu anlaşılmaz” gibi yanıtlar alınmıştır. Tarihsel 
kökenlerine dair bilinçli bir üretim gerçekleşmemesine karşın bölgelere göre farklılık gösteren bezeme türlerinin uzun zamandır değişmeden yapılıyor olması ve adeta bölgesel işaret olarak varlıklarını sürdürüyor olmaları yeni ve derinlemesine araştırmaların zeminini oluşturacak kapsamdadır.

Anadolu'da çömlek üretimi, 1900'lü yılların başından günümüze azalarak devam etmektedir. Bu sebeple, üretimin bittiği yörelerde bahsi geçen gelenek ve inanışlar üretimle birlikte yok olmuştur. Üretimin devam ettiği merkezlerde ise değişen ve gelişen toplum yapısı ile birlikte bu üretimlere bağlı gelenek ve inanışlar da son bulmuştur.

Makale kapsamında, konu ile ilgili bilgilerin çoğu Cumhuriyetin ilk yıllarında araştırma yapan değerli etnolog ve arkeologların literatüre sağladığı katkılar sayesinde edinilmiştir. Ayrıca, üretimin sona ermeğe başladığı dönem olan 1970-1990'lı yıllar arasında yapılan seramik alan araştırmalarından gelenek ve inanışlar ile ilgili çok değerli veriler elde edilmiştir. Bu veriler doğrultusunda günümüzde üretime devam eden merkezler ile ilgili araştırmalar disiplinler arası çalışmalarla detaylandırılıp, zenginleştirilebilir. Kültürel mirasın korunması ve üretimin devamlılığın sağlanması maksadıyla yapılacak ortak akademik çalışmalar ülke ekonomisine katkı sağlayacağı gibi zengin kültür mirasına sahip Anadolu çömlekçiliğinin farklı ülkelerde tanıtılmasına da fayda sağlayacağı öngörülmektedir.

\section{Kaynakça}

Akça, G. (2009). Diyarbakır ili Ergani ilçesi halk kültürü araştırması (Yüksek Lisans Tezi). YÖK tez veri tabanından erişildi (Tez No. 230594).

Balaman, A. R. (1983). Gelenekler töre ve törenler. İzmir: Betim Yayınlar1-Halkbilimi (Folklor) dizisi:1.

Balaman, A. R. (1985). Kütahya'da geleneksel seramikçilik. 4. Ulusal El Sanatları Sempozyumunda sunulan bildiri. İzmir: Dokuz Eylül Üniversitesi.

Daşdağ, F. E. (2001). Diyarbakır çömlekçiliği (Yüksek Lisans Tezi). YÖK tez veri tabanından erişildi (Tez No. 113127)

Daşdağ, F. E. (2005). The pottery of Sanliurfa. Ceramics Technical, 21, 89-91.

Ertuğ, F. (2004). Pottery production at Uslu in the Elazı̆̆ region. T. Takaoğlu (Ed.), Etnoarchaeological Investigations in Rural Anatolia Volume I (s.77-93) içinde. İstanbul: Ege Yayınları.

Güner, G. (1988). Anadolu'da yaşamakta olan ilkel çömlekçilik. İstanbul: Ak Yayınları Kültür Serisi 16-5.

Koç, A. (2016). Eşikteki mücadele: Anadolu düğünlerinde kaynana-kaynata güreşi. Uluslararası Sosyal Araştırmalar Dergisi, 9(42), 252-274. Erişim adresi: http://www.sosyalarastirmalar.com/cilt9/sayi42_pdf/ 1dil_edebiyat/koc_adem.pdf

Koşay, H. Z., \& Ülkü, A. (1962). Anadolu'da iptidai çanak-çömlekçilik. Türk Etnografya Dergisi, V, 89-93.

Sarıtaş, S. (2019). Halkbiliminde maddi kültüre teorik ve metodolojik yaklaşımlar. Milli Folklor, 122, 29-40. Erişim adresi: http://www.millifolklor.com/PdfViewer.aspx?Sayi=122\&Sayfa=31

Tuncer, T. (2017). Kutsal ve geleneksel günler. (N. Doğan, Ed.), Bolu ve mutfak kültürü No. 18 (s. 47-50) içinde. Erişim adresi: $\quad$ http://bamer.ibu.edu.tr/attachments/article/708/Bolu\%20ve\%20Mutfak $\% 20 \mathrm{~K} \% \mathrm{C} 3 \%$ BClt $\%$ C3\%BCr\%C3\%BC-comp.pdf

Tüzün, M. Z. (2018, 8 Eylül). 7 kuşaktır çamura şekil veriyorlar. Erişim adresi: https://www.milliyet.com.tr/ yerelhaberler/nevsehir/7-kusaktir-camura-sekil-veriyorlar-13020911

Ünal, S. (1996). Diyarbakır çömlekçiliğii. Sanatsal Mozaik, 13, 66-70.

Yalgın, A. R. (1940). Çok iptidai çömlekçilik. Türk Tarih, Arkeologya ve Etnografya Dergisi, IV, 193-201.

Yalgın, A. R. (1945). Çok iptidai çömlekçilik. Çalışma Mecmuası, 1, 80-85.

Yalgın, A. R. (1977). Cenupta Türkmen oymakları I. S. Emir (Haz.). Ankara: Kültür Bakanlığı Yayınları: 256, Kültür Eserleri:14.

Yardımcı, İ., \& Bardak, M. (2019). Geleneksel Karacasu çömlekçiliği ve gelin testisinin gelişimi ve günümüz yorumlamaları. Uşak Üniversitesi Sosyal Bilimler Dergisi, XII, 82-98. Erişim adresi: https://dergipark.org.tr/ tr/pub/usaksosbil/issue/51480/629423

Yiyin, A. (2009). Türk kültüründe asker ocă̆ı etrafinda oluşan halk bilimi ve halk edabiyatı ürünleri üzerinde bir inceleme (Yüksek Lisans Tezi). YÖK tez veri tabanından erişildi (Tez No. 240547). 


\section{Görüşmeler}

2011.KB.SOS.010 numaralı Bilimsel Araştırma Projesi, (2011-2015) Günümüzde Anadolu'da Yaşayan İlkel Çömlekçilik Merkezleri, Dokuz Eylül Üniversitesi, Proje Yöneticisi Prof. Sevim Çizer, Çalışanları: Uzm. Arkeolog Selim Martin, Doktora Öğrencisi Dicle Öney

Arıkan, İ. (2012, 22 Ağustos). Hüyük çömlekçiliği. (S. Martin ve D. Öney, Röportajı Yapan)

Bozkurt, H. (2012, 22 Haziran). Elazı ̆̆ çömlekçiliği. (S. Çizer ve D. Öney, Röportajı Yapan)

Eğidoğan, M. (2012, 22 Ağustos). Doğanhisar çömlekçiliği. (S. Matin ve D. Öney, Röportaj1 Yapan)

Karayiğit, S. (2020, 1 Mayıs). Ünye çömlekçiliğii. (F. Öztürk, D. Öney, Röportajı Yapan)

Kargın, İ. (2012, 22 Eylül). Şereflikoçhisar çömlekçiliği. (S. Martin ve D. Öney, Röportajı Yapan)

Kaynak, Ş. (2012, 9 Eylül). Mardin çömlekçiliğii. (S. Martin, Röportajı Yapan)

Koğumtekin, M. (2012, 9 Eylül). Mardin çömlekçiliği. (S. Martin, Röportajı Yapan)

Köse, M. (2015, 5 Haziran). Esenköy çömlekçiliği. (D. Öney, Röportajı Yapan)

\section{Görsel Kaynakçası}

Görsel 1. Daşdağ, F. E. (2001). Diyarbakır çömlekçiliği (Yükssek Lisans Tezi). YÖK tez veri tabanından erişildi (Tez No. 113127). s. 61

Görsel 2. Yalgın, A. R. (1940). Çok iptidai çömlekçilik. Türk Tarih, Arkeologya ve Etnografya Dergisi, IV, 198199.

Görsel 3. 2011.KB.SOS.010 numaralı Bilimsel Araştırma Projesi Arşivi

Görsel 4. 2011.KB.SOS.010 numaralı Bilimsel Araştırma Projesi Arşivi

Görsel 5. a) Altınkılıç, A. E. (2013). Karacasu çömlekçiliği'nden yola çıkılarak hediyelik ürün tasarımı ve uygulaması (Yüksek Lisans Tezi). YÖK tez veri tabanından erişildi (Tez No.413916). s. 45

b) Çalışıcı, P. (2003). Ege bölgesinde geleneksel çömlekçiliğin bugünkü durumu (Yüksek Lisans Tezi). YÖK tez veri tabanından erişildi (Tez No. 130198). s.10

c) Sadakatin Sembolü Gelin Testisi. (2013, 3 Ekim). Objektif Haber, Haber Bülteni. Erişim adresi: http://www.objektifhaber.com/sadakatin-sembolu-gelin-testisi-202179-haber/

d-e-f) Yardımcı, İ., \& Bardak, M. (2019). Geleneksel Karacasu çömlekçiliği ve gelin testisinin gelişimi ve günümüz yorumlamaları. Uşak Üniversitesi Sosyal Bilimler Dergisi , XII, 82-98. s. 95

Görsel 6. Öğr. Gör. Selim Martin kişisel arşivi

Görsel 7. 2011.KB.SOS.010 numaralı Bilimsel Araştırma Projesi Arşivi

Görsel 8. Ertuğ, F. (2004). Pottery production at Uslu in the Elazlğ region. T. Takaoğlu (Ed.), Etnoarchaeological Investigations in Rural Anatolia Volume I (s.77-93) içinde. İstanbul: Ege Yayınları. s. 95

Görsel 9. a) Yalgın, A. R. (1940). Çok iptidai çömlekçilik. Türk Tarih, Arkeologya ve Etnografya Dergisi, IV, 193 201. s. 200

b) Yalgın, A. R. (1940). Çok iptidai çömlekçilik. Türk Tarih, Arkeologya ve Etnografya Dergisi, IV, $193-201$. s. 195

Görsel 10. Yalgın, A. R. (1977). Cenupta Türkmen oymakları I. S. Emir (Haz.). Ankara: Kültür Bakanlığ Yayınları: 256, Kültür Eserleri:14. s. 149 